\title{
WASTE RECYCLING, THE NEW-OLD CHALLENGE FOR SUSTAINABLE URBAN DEVELOPMENT
}

\author{
PhD. Student Cosma Ioana Gabriela \\ Romanian Academy, National Institute for Economic Research "Costin C. \\ Kiritescu" Ph.D. Student (ROMANIA) \\ gabrielacosma11@gmail.com
}

\begin{abstract}
At present, there are many challenges facing cities and affecting their ability to create jobs and prosperity, without endangering the environment and resources. Among the most common urban challenges we can list traffic congestion, inadequate housing, air, soil and water pollution, green areas, waste of all kinds etc. These challenges can be overcome in order to continue sustainable urban development based on resource efficiency and aiming at reducing pollution and poverty. The future of cities includes opportunities for all inhabitants, reducing economic and social inequalities.
\end{abstract}

Seen as opportunity and challenge at the same time, waste recycling due to the economic and social growth of cities has a positive impact on the local environment (air, water, land, human health etc.). Therefore, the complexity, costs and coordination of waste management require the involvement of all stakeholders, but also financial resources, including the identification of new technologies, research actions and eco-innovation.

This article aims to address, in a synthetic way, the issue of urban waste recycling, which is currently considered as a major source of urban pollution, an important factor affecting the quality of life and living, as well as the prospects for sustainable urban development.

Keywords: Bio-economy, Recyclable Materials, Sustainable Urban Development.

\section{INTRODUCTION}

The city is the central element of territorial, economic and social development policies, a landmark of modern society, a pattern of existence increasingly mimicked and sought, on a regional or global scale.

The urban area is considered a form of unification of the different social groups in relation to the natural environment and to the spiritual, cultural, historical values of humanity. Without excessive idealization, the city can be considered a living organism: it breathes, it grows, it has a past and a future, culture, traditions, it consumes raw materials, natural resources, technologies etc.

If consumption exceeds certain tolerance limits, the city is in contradiction with the values and principles of sustainable development. Among the values of sustainable development established by the European Commission (1993) we can list: maintaining the quality of life in full, maintaining continuous access to natural resources and avoiding permanent damage to the environment. 


\section{\#3/2018 URBAN CHALLENGES}

From the perspective of the strategic management of sustainable development, there are set a series of long-term (15-20 years) objectives, compatible with those on short and medium term, applied with the help of internationally validated principles and criteria. One of these principles refers to the lifecycle approach of goods, services and technologies, assessing the environmental consequences generated by the economic effects resulting from different stages of processing and capitalizing on market products. To this principle, we can add others such as intergenerational equity, precaution, prevention, substitution, the "polluter pays, principle, the internalization of positive externalities etc. Urban strategic management encompasses all of the above principles, applied at city level, maintained over a long period of time.

Taking into account the specific ${ }^{1}$ functions of cities (depending on the location of the city on the territory, the natural resources, the climatic conditions, the environment, the historical evolution, the socio-economic conditions, the economic policy, etc.), urban management is the combination of all the flows converging to ensure the welfare of the inhabitants and the sustainable development of the area [1].

In a city, in order to make things to work properly, it is inevitable that all the constituents work well, complementing and supporting each other. One of these elements relates to the waste collection / storage / recycling process. The importance of waste management is relevant both globally and especially locally where efficient, effective action can be taken to find the best solutions and methods for eliminating or mitigating large quantities of waste resulting from intensive economic and social activities.

In view of the above, the article aims to address, in a synthetic way, the issue of urban waste recycling, which is, at present, a major source of pollution, an important factor affecting the quality of living and the prospects of sustainable development.

\section{THEORETICAL ASPECTS OF URBAN WASTE MANAGEMENT}

In the beginning, human interaction with the environment was a gentle, friendly one, but with time, with the development and evolution of human society, this relationship turned into a toxic, polluting one, we can even say a destructive one.

Cities have begun to go through the long road of development, and the initial parameters have changed. Urban development has resulted in a number of technical and socio-economic processes that have led to an increase in the amount of goods and services, energy consumption and fuels, but also to the occurrence of residues / waste. This waste began to be produced in increasing quantities, affecting the environment, the life and health of urban residents. From this point on, waste has become a problem that any urban management has to deal with and needs to solve, both theoretically and practically.

\footnotetext{
${ }^{1}$ Urban functions can be: Serving the city, serving the city's population, which have local importance and basic functions or city-generating functions, through which the city develops, has connections with the areas from which it gets its supplies and where its breaking down production. The basic functions are the most important: the city becomes known, creating its personality.
} 


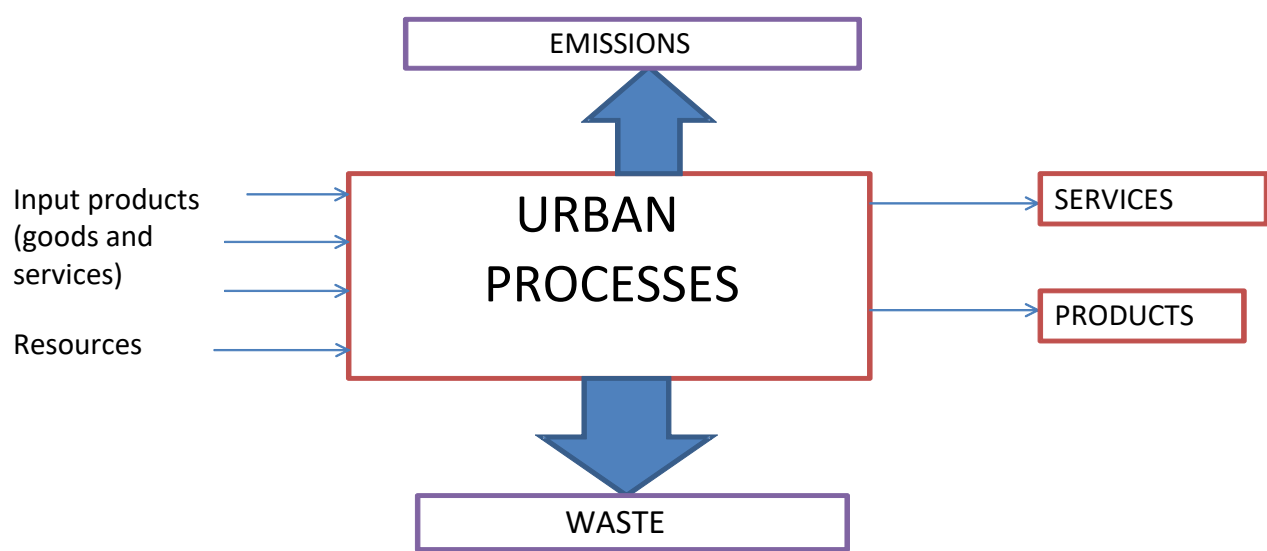

Fig.1. Urban process - a general framework Source: [2]

As can be seen from the above figure, any urban process has as a final result in addition to the products and services demanded by the market, waste and emissions (gas, solid particles, etc.) considered in the economic literature as negatives. These negatives are, in fact, costs incurred by a third party as a result of economic transactions. In a transaction of an economic nature, the producer and the consumer are the main parties, while the third party includes any person, organization, owner or resource indirectly affected. Negatives are called side effects, thus becoming an external cost. Some negatives, such as waste, come from consumption, while others, such as carbon emissions from factories and plants, are the result of production [3].

Through the free market, negatives introduce a series of distortions in the resource allocation system, distortions that can be mitigated by applying the Polluter Pays Principle (PPP), which has two important functions:

1. Establishes responsibility for the pollution caused;

2. Allows prices to be allocated to environmental resources so that producers can take account of their importance in the production process [4].

In theory, the relationship between sustainable development and the recycling of urban waste has been strongly debated within the mainstream of regional science. Thus, from an economic perspective, there is a real and serious conflict between the tendency to consume a great deal of resources (no matter their nature) and the recycling of waste resulting from different activities [5]. This is where the decision of the city authorities comes: that a product may or may not be considered waste (or residue) according to the subjective opinion of the consumer.

There are various theories and models relevant to the analysis of the consumer behavior in relation to waste recycling. Some theories are based only on statistic data and information regarding recycling, while others have developed as general theories of self-sustaining behavior (Theory of Rational Action, Planned Behavior Theory, Schwartz Altruism Model etc.) [6].

From a theoretical perspective, recycling turns unusable products into new products that can later be re-usable in other actions. Urban recycling is a physical process, but can also be seen from a social, cultural perspective etc. In cities, waste recycling can help encourage business / services, along with reducing 


\section{\#3/2018 URBAN CHALLENGES}

poverty concentration, create new jobs, stimulate additional private investment etc.

According to the Department of Urban Studies and Planning of the Massachusetts Institute of Technology, waste recycling can bring benefits that can be grouped into three categories [7]:

a. Economic benefits: investment acquisition; increasing fiscal income; improving city competitiveness; increasing the value of real estate; increasing the efficiency of the use of city infrastructure and land resources;

b. Social benefits: increasing employment opportunities; improving the quality of life of the inhabitants; mitigating risks for human health;

c. Environment benefits: improving the quality of the urban environment; reducing greenhouse gas emissions; reducing the pressure on green space.

At present, the circular economy and its significance are increasingly discussed in the context of solving municipal waste problems and their recycling. From the perspective of the circular economy, the reuse of urban waste determines the reduction of the amount of municipal waste (cities, urban areas), the reduction of environmental pollution and obtaining of additional revenues [8].

Circular economy can be an important way of solving urban pollution and reducing waste resulting from different processes, based on the following features:

1. Each urban system generates two categories of waste: some that can be recycled and others that can be stored (a material can be recycled if advanced technologies are available, and storage is also closely related to the city's ability to neutralize the waste);

2. Waste recycling methods should not be toxic to the urban population;

3. Organic substances should not be disposed of by storage (organic compounds must be recycled or recovered, resulting in compost or biogas);

4. Final storage must be done with priority in mono-substance locations.

Although there is only one form of waste collection, namely the separate one, there are several forms of waste treatment (composting, incineration, etc.) and several categories of products (compost, heat, energy etc.) (Table no. 1).

\begin{tabular}{|l|c|c|c|c|c|}
\hline Category & Source & Treatment & $\begin{array}{c}\text { Final } \\
\text { product }\end{array}$ & Market & $\begin{array}{c}\text { Emissions in } \\
\text { the } \\
\text { environment }\end{array}$ \\
\hline $\begin{array}{l}\text { Vegetable } \\
\text { and animal } \\
\text { waste }\end{array}$ & $\begin{array}{l}\text { Separate } \\
\text { collection }\end{array}$ & Composting & Compost & Horticulture & Gas \\
\hline $\begin{array}{l}\text { Municipal } \\
\text { Waste }\end{array}$ & $\begin{array}{l}\text { Separate } \\
\text { collection }\end{array}$ & Incineration & $\begin{array}{c}\text { Thermal } \\
\text { energy }\end{array}$ & $\begin{array}{c}\text { Heating of } \\
\text { dwellings }\end{array}$ & $\begin{array}{c}\text { Ash, waste, } \\
\text { purified water, } \\
\text { purified gas }\end{array}$ \\
\hline $\begin{array}{l}\text { Municipal } \\
\text { waste }\end{array}$ & $\begin{array}{l}\text { Separate } \\
\text { collection }\end{array}$ & $\begin{array}{c}\text { Municipal } \\
\text { warehouses }\end{array}$ & Biogas & Energy & Mud \\
\hline
\end{tabular}

Table no. 1: Ways of recycling certain categories of urban waste 
In order to assess the impact of waste on the environment, a series of methodologies, presented in a synthetic way, are presented in the table below (Table no. 2):

\begin{tabular}{|l|l|}
\hline & \multicolumn{1}{|c|}{ Methods of impact environmental assessment } \\
\hline 1 & Activity-Based Costing (ABC)/ Cost-Benefit Analysis (CBA) / Total Cost Assessment (TCA) \\
\hline 2 & Analytical Hierarchy process (AHP) \\
\hline 3 & Balanced Scorecard Approach (BSC) \\
\hline 4 & Carbon Footprint (CF, Corporate Carbon Footprint, Product Carbon Footprint) \\
\hline 5 & Comparative Risk Assessment (CRA) \\
\hline 6 & Corporate Social Responsibility (CSR) \\
\hline 7 & Drives-Pressures-State-Impact-Response (DPSIR) \\
\hline 8 & Eco-Efficiency (EE) [9] \\
\hline 9 & Ecological Footprint (EF) \\
\hline 10 & Economic Input-Output (EIO) \\
\hline 11 & Material Flow Analysis (MFA)/ Energy Flow Analysis \\
\hline 12 & Environmental Impact Assessment (EIA) \\
\hline 13 & Environmental Profit and Loss (EP\&L) \\
\hline 14 & Life Cycle Assessment (LCA)/ Life Cycle Costing (LCC)/Life Cycle Working Environment \\
\hline 15 & (LCWE) \\
\hline 16 & Multi-Criteria Decision Making (MCDM) \\
\hline 17 & Social Life Cycle Assessment (SLCA) \\
\hline 18 & Strategic Environmental Assessment (SEA) \\
\hline 19 & Sustainability Assessment (SA) \\
\hline 20 & Urban and Industrial Symbiosis (UIS) [10] / Industrial Symbiosis (IS) \\
\hline
\end{tabular}

Table no. 2: The methodologies of impact environmental assessment

Source: Author computations

Regarding the methods presented in Table no. 2, nearly three-quarters of them are based on product life-cycle assessment, which is one of the most important milestones in sustainability and environmental impact assessment. Approximately $50 \%$ of the methods take into account information and data from the material flow regarded as input in the evaluation process. Also, $54 \%$ of the methods contain elements that allow examination of social aspects during the evaluation. Most of the methods work with economic data and allow for economic assessments (76\%) and $81 \%$ of all the methods presented are appropriate for environmental assessment.

The main assessment indicator is the Urban Waste Recycling Rate, calculated as follows (Table no. 3): 


\begin{tabular}{|c|c|}
\hline 1. Calculate total waste disposed & \\
\hline A. Calculate MSW Disposed of Category & Total Amount \\
\hline \multicolumn{2}{|l|}{ Total MSW } \\
\hline B. Exclude materials not included in MSW Category & Total Amount \\
\hline \multicolumn{2}{|l|}{ Commercial waste } \\
\hline \multicolumn{2}{|l|}{ Other } \\
\hline \multicolumn{2}{|l|}{ Total excluded waste } \\
\hline Total MSW Disposed of (tons) & $C=A-B$ \\
\hline \multicolumn{2}{|l|}{ 2. Calculate total recycling } \\
\hline \multicolumn{2}{|l|}{ D. Calculate Recyclables (MSW Recycled) from all sources } \\
\hline \multicolumn{2}{|l|}{ Category } \\
\hline \multicolumn{2}{|l|}{ Total MSW Recycled } \\
\hline \multicolumn{2}{|l|}{ E. Exclude what is not considered recycled } \\
\hline \multicolumn{2}{|l|}{ Category } \\
\hline \multicolumn{2}{|l|}{ Residual waste sent to landfill } \\
\hline \multirow{2}{*}{\multicolumn{2}{|c|}{ Contaminated recyclables sent to landfill }} \\
\hline Total excluded recyclables & \\
\hline F. Total MSW Recycled & $F=D-E$ \\
\hline 3. Calculate MSW Recycling Rate (\%) & {$[F \div(F+C)] \times 100$} \\
\hline
\end{tabular}

Table no. 3: The main steps to calculating the MSW recycling rate. Note: MSV=Municipal Solid Waste Recycling Rate (\%) Source: [11]

We can say in conclusion that recycling is an important part of a sustainable urban lifestyle. Unfortunately, the vital role of recycling at present is often misunderstood: although many people are familiar with recycling, the depths of this action are generally subtle and often ignored. Therefore, there is a need for a better understanding of the sustainability and impact of recycling on the quality of urban life, as well as a familiarization and publicity of the benefits of this recycling process [12].

\section{URBAN WASTE RECYCLING IN THE EUROPEAN UNION}

At European Union level, waste management is based on three major principles:

1. preventing waste generation - this principle involves important investments in technologies and new production methods, accompanied by transformation of consumer mentality into green products and a new lifestyle that generates small amounts of waste.

2. recycling and reuse - involves recovering component materials, preferably through material recycling. For this purpose, several waste streams are identified for which material recycling is a priority: packaging waste, end-of-life vehicles, battery waste, and electrical, electronic equipment waste.

3. improving final waste disposal and monitoring - addresses waste that cannot be recovered, and must be disposed of in safe conditions for the environment and human health, with a strict monitoring program.

Along with the principles highlighted above, there are important legislation in the EU governing the packaging market and packaging waste market [13]. 


\section{\#3/2018 URBAN CHALLENGES}

In the European Union, there are major differences in the management of solid municipal waste throughout the Member States, the most important being the ratio between the storage of waste and its recycling. Storage - a relatively "bad" management option - is unfortunately still the main means of waste disposal in many Member States. According to the Community Roadmap entitled "Resource Efficiency", landfilling should be practically reduced to a minimum (set for 2020 and 2030).

The European waste directives are based on the "pay for how much you throw" system with responsibilities for each actor involved in the municipal waste management chain. Also, the extended producer responsibility, as defined by the new European approach in the context of the current Circular Economy, is based on a package to amend six Directives that will create development opportunities for a circular economy, boosting global competitiveness, sustainable economic growth and generating new jobs.

Much of the waste in Europe could be recycled.

Recycling brings benefits to the environment by eliminating waste from landfills and supplying raw materials for new products. Recycling can also encourage innovation and job creation. In Europe, in 2016, according to the European Environment Agency, the first place for recycling is awarded to Germany with $66.1 \%$, Austria $57.6 \%$, Belgium $53.5 \%$ and the Netherlands $53.1 \%$. The last places are held by Malta with $7.1 \%$, Romania with 13.3 and Greece with $17 \%$ (Figure no. 1).

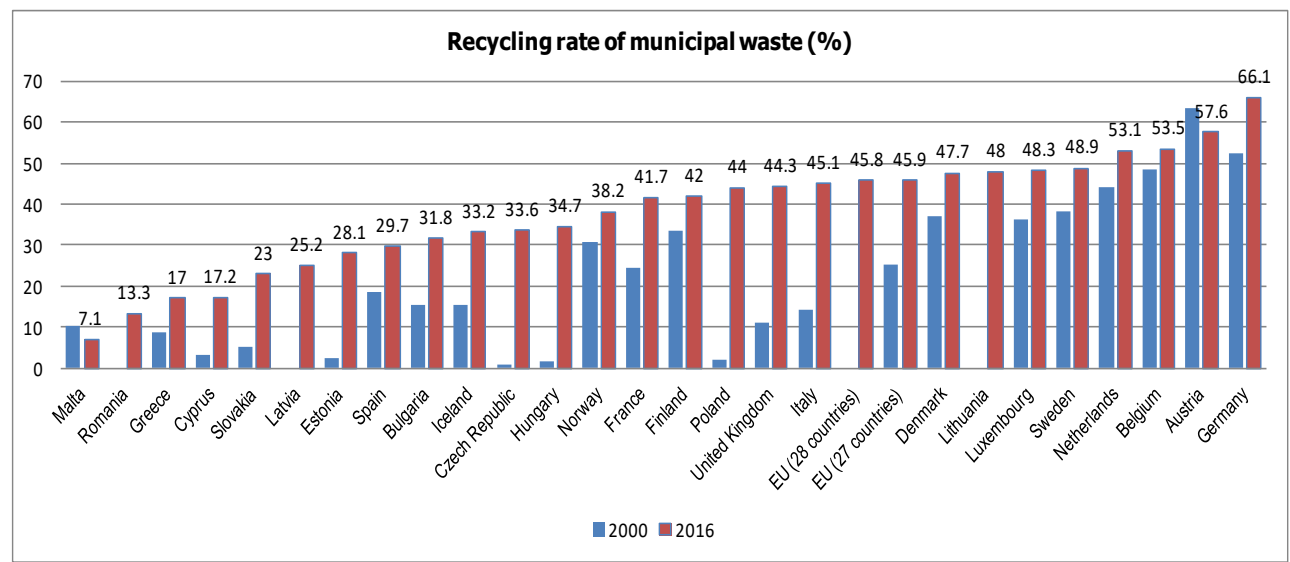

Figure no. 1 - Recycling rates of municipal waste in Europe, in 2016 vs. 2000 (\%) Source: [14]

The European Commission has adopted a new vision for future development, namely that based on the Circular Economy, which includes a revised legislative package on waste and which will directly contribute to increasing global competitiveness, sustainable growth and will generate new jobs [15]. Revised legislative proposals establish a clear understanding of waste management and recycling. Ensuring effective implementation of these legislative proposals leads to the establishment of revised targets on the Circular Economy [16]:

- EU Common Recycling Target: 65\% of municipal waste by 2030; 


\section{\#3/2018 URBAN CHALLENGES}

- A common EU target for recycling $75 \%$ of packaging waste by 2030 ;

- A binding landfill target to reduce landfill to maximum $10 \%$ of municipal waste by 2030;

- A ban on landfilling of separately collected waste;

- Promotion of economic instruments to discourage landfilling;

- Simplified and improved definitions and harmonized calculation methods for recycling rates throughout the EU;

- Concrete measures to promote re-use and stimulate industrial symbiosis turning one industry's by-product into another industry's raw material;

- Economic incentives for producers to put greener products on the market and support recovery and recycling schemes (Table no. 4).

\begin{tabular}{|c|c|c|c|c|}
\hline & \multicolumn{2}{|c|}{ EU Commission } & \multicolumn{2}{|c|}{ EU Parliament } \\
\hline & 2025 & 2030 & 2025 & $\begin{array}{c}203 \\
0\end{array}$ \\
\hline $\begin{array}{l}\text { Share of municipal waste prepared for reuse and } \\
\text { recycling }\end{array}$ & $60 \%$ & $65 \%$ & $60 \%$ & $\begin{array}{l}70 \\
\%\end{array}$ \\
\hline Share of bio-waste prepared for recycling & & & $50 \%$ & $\begin{array}{l}65 \\
\%\end{array}$ \\
\hline Share of municipal waste landfilled & & $10 \%$ & & $5 \%$ \\
\hline $\begin{array}{l}\text { Share of packaging waste prepared for reuse or/and } \\
\text { recycling }\end{array}$ & $65 \%$ & $75 \%$ & $70 \%$ & $\begin{array}{l}80 \\
\%\end{array}$ \\
\hline Share of packaging waste prepared for reuse & & $5 \%$ & & $\begin{array}{l}10 \\
\%\end{array}$ \\
\hline $\begin{array}{l}\text { Share of plastic packaging prepared for reuse and } \\
\text { recycling }\end{array}$ & $55 \%$ & $60 \%$ & $50 \%$ & $\begin{array}{l}70 \\
\%\end{array}$ \\
\hline $\begin{array}{l}\text { Share of wood packaging prepared for reuse and } \\
\text { recycling }\end{array}$ & & $60 \%$ & & $\begin{array}{l}75 \\
\% \\
\end{array}$ \\
\hline $\begin{array}{l}\text { Share of ferrous metal packaging prepared for reuse } \\
\text { and recycling }\end{array}$ & & $75 \%$ & & $\begin{array}{l}85 \\
\%\end{array}$ \\
\hline $\begin{array}{l}\text { Share of aluminum packaging waste prepared for } \\
\text { reuse and recycling }\end{array}$ & $75 \%$ & $85 \%$ & $80 \%$ & \\
\hline $\begin{array}{l}\text { Share of glass packaging prepared for reuse and } \\
\text { recycling }\end{array}$ & $75 \%$ & $85 \%$ & $80 \%$ & \\
\hline $\begin{array}{l}\text { Share of paper and cardboard packaging waste } \\
\text { prepared for reuse and recycling }\end{array}$ & $75 \%$ & $85 \%$ & $90 \%$ & \\
\hline $\begin{array}{l}\text { Calculation method for recycling quotas - Separate } \\
\text { collection *Exceptions Member States with }<20 \% \text { rate } \\
\text { of recycling in } 2013 \text { or expecting to }<50 \% \text { in } 2025 \\
\text { (received } 5 \text { years more) }\end{array}$ & $\begin{array}{l}\text { only one calc } \\
\text { for all membe } \\
\text { in final recy }\end{array}$ & $\begin{array}{l}\text { lation-method } \\
\text { states. Input } \\
\text { ling process }\end{array}$ & $\begin{array}{l}\text { averag } \\
\text { e loss } \\
\text { rate }^{2}\end{array}$ & \\
\hline Separate collection & $\begin{array}{l}\text { Paper } \\
\text { \&cardboard, } \\
\text { metal, } \\
\text { plastic, glass }\end{array}$ & $\begin{array}{l}\text { Paper } \\
\text { \&cardboard, } \\
\text { metal, } \\
\text { plastic, } \\
\text { glass, } \\
\text { textile, bio- } \\
\text { waste }\end{array}$ & & \\
\hline
\end{tabular}

Table no. 4: Targets of European Parliament and Commission regarding to municipal waste

Source: [17]

\footnotetext{
${ }^{2}$ New Calculation Method for recycling targets is "Average loss rate", based on subtracted from the separate collected fractions. It differs from type of waste and treatment process.
} 


\section{\#3/2018 URBAN CHALLENGES}

\section{RECYCLING OF MUNICIPAL WASTE IN ROMANIA}

In Romania, the recycling of municipal waste is the responsibility of local authorities and is regulated by Law no. 101/2006 on sanitation of localities. Sanitation activities are carried out by licensed operators [18], municipal waste being collected from generators (domestic and non-household) and transported to treatment / recycling / recovery facilities and / or disposal facilities. Installations are the responsibility of environmentally authorized operators and they report annually to environmental authorities' data on the quantities of waste managed.

At national level, around 421 economic operators are licensed for municipal waste collection, transport and storage activities (including the provision of street cleaning and snow removal services), of which 4 economic operators are community legal entities.

In 2015, according to EUROSTAT, of the 272 kilograms of household waste generated in one year by a Romanian, only $3 \%$ is recycled. This percentage places Romania on the last place in the European Union. It should be remembered that Romania should recycle $50 \%$ of municipal waste (including at least paper, metal, plastic and glass) by 2020, according to the objectives set by the European Waste Framework Directive (Directive 2008/98/ EC).

Failure to meet EU targets will result in sanctions through the Infringement procedure applied by the European Court of Justice (Table no. 5 ).

\begin{tabular}{|l|l|l|l|l|l|r|}
\hline & 2010 & 2011 & 2012 & 2013 & 2014 & $\begin{array}{l}2014 / 2010 \\
(\%)\end{array}$ \\
\hline $\begin{array}{l}\text { Paper and } \\
\text { cardboard }\end{array}$ & 32.201 & 37.880 & 43.579 & 46.316 & 50.042 & 55.41 \\
\hline Plastic & 26.757 & 48.452 & 48.452 & 39.573 & 46.638 & 74.30 \\
\hline Metals & 1.201 & 1.642 & 2.235 & 2.600 & 2.479 & 106.41 \\
\hline Wood & 2.332 & 2.842 & 7.572 & 2.581 & 3.074 & 31.82 \\
\hline Glass & 11.716 & 7.652 & 23.716 & 19.402 & 13.197 & 12.64 \\
\hline Bulky & 23.322 & 14.388 & 26.214 & 49.794 & 28.274 & 21.23 \\
\hline Textiles & 48 & 147 & 480 & 167 & 260 & 441.67 \\
\hline Biodegradables & 32.922 & 30.688 & 31.545 & 30.952 & 20.934 & -36.41 \\
\hline Other waste & 14.707 & 12.890 & 724 & 5.264 & 6.415 & -56.38 \\
\hline
\end{tabular}

Table no. 5: Separate collection of household and similar waste by sanitation operators, in Romania

Source: [18]

In Romania, landfill waste disposal is not properly taxed, so the recycling process is not stimulated, with sanitation firms choosing to store waste collected for economic reasons. The storage fee at the pit is only 10-15 euro / ton while in other European countries it exceeds 100 euro / ton. Appropriate taxation should have been applied to waste deposited as early as 2014, but in December 2013 the authorities postponed the tax until 2017. As of January 1, 2017, the tax will be 80 lei / ton (17.7 euro) and will increase to 120 RON ( $€$ 26.6) per ton in 2018. Law no. $211 / 25.11 .2011$ transposes into the national legislation the European Waste Framework Directive. According to this, all economic operators / producers of waste are forced to selectively collect the waste, at least 4 categories (paper, metal, plastic, glass). Legal entities that do not comply with these regulations may 


\section{\#3/2018 URBAN CHALLENGES}

receive fines ranging from 20,000 to 40,000 RON, applied by the National Environmental Guard and the local public administration.

According to ANPM data, in 2014, the material recycling rate was about $5 \%$ and the composting rate of about $8 \%$. Given that about 40,000 tons of municipal waste was treated in authorized composting facilities this year, it is possible that all the waste estimated as composted will be overestimated (Table no. 6).

\begin{tabular}{|l|c|c|c|c|c|c|}
\hline & 2010 & 2011 & 2012 & 2013 & 2014 & 2015 \\
\hline $\begin{array}{l}\text { Municipal waste } \\
\text { generated } \\
\text { (tons/year) }\end{array}$ & 6.343 .144 & 5.216 .162 & $\begin{array}{c}5.044 .12 \\
1\end{array}$ & 5.070 .805 & 4.956 .075 & 4.895 .000 \\
\hline $\begin{array}{l}\text { Treated municipal } \\
\text { waste - total } \\
\text { (tons/year)* }\end{array}$ & 6.031 .780 & 5.190 .462 & $\begin{array}{c}4.553 .76 \\
1\end{array}$ & 4.889 .200 & 4.947 .536 & \\
\hline $\begin{array}{l}\text { Capitalization } \\
\text { (tons/year) }\end{array}$ & 1.218 .190 & 1.104 .678 & 1.029 .334 & 951.650 & 1.041 .812 & \\
\hline Recycling rate (\%) & 12,79 & 11,69 & 14,78 & 13,21 & 13,07 & \\
\hline
\end{tabular}

Table no. 6: Managing municipal waste, 2010-2015

Source: [19]

* The difference between the total amount of municipal waste generated and the total amount of municipal waste treated comes from the end-of-year stocks and from the losses occurring during the interim treatment.

The infrastructure for municipal waste treatment consists of 150 existing sorting facilities at national level (in operation and built by POS / POIM projects to be put into operation), 45 were built through SMID projects, financed by POS Environment, respectively ISPA (in the counties of Dâmboviţa and Teleorman). Although all 45 plants were designed for the collection of separately collected recyclable waste, the three that work (Dâmboviţa, Teleorman and Bistriţa-Năsăud) also ensure sorting of municipal waste collected as mixture. The total capacity of the 45 sorting plants is about 840,500 tons / year, accounting for about $56 \%$ of the amount of recycled waste generated in 2014 (less wood and textiles, waste that supposedly doesn't reach the sorting facilities).

As far as the mechanical and biological treatment facilities (TMB) are concerned, in 2017, in addition to the existing installations in operation (Chiajna / Bucharest, Ghizela / Timis), another new plant was put into operation at Borcea Mare / Hunedoara. In addition to these three plants, another 14 plants are still being built by SMID projects. The total capacity of TMB plants is $1,459,000$ tons / year. The built TMB plants are all bio stabilizing plants, ensuring waste treatment before storage. Mechanical treatment consists of separating waste into fractions (generally by size) and magnetic separation of ferrous waste. In some cases, the sorting of fractions that are subsequently sent to recycling is done. Biological treatment is aerobic - in some cases in covered areas. The resulting stabilized waste is stored or used as covering material on deposits. In Romania, in only 12 counties, a pre-treatment of the entire quantity of waste is ensured, this being ensured through the TMB installations and the composting facilities built by SMID. In the counties of Timiş, Bihor, Mureş, Vâlcea and Bucharest, the TMB installations were not designed to ensure the treatment of the entire quantity of waste collected.

At present, the national recycling capacity consists of [20]:

- paper and cardboard - about 665,000t/year; 


\section{\#3/2018 URBAN CHALLENGES}

- plastic- about 284,000 t/year of which 134,000 t/year for PET waste, and 150,000 t/year for other plastic waste;

- metal - about 2,700,000 t/year, of which about 2,500,000 t/year for ferrous waste, and about 200,000 t/year for non-ferrous waste;

- glass - about 122,000 t/year.

It is considered that there is sufficient recycling capacity for paper and cardboard waste to reach the $50 \%$ municipal waste target of 2020 [20]. For plastic and glass waste, current theoretical recycling is not enough compared to the quantity that should be collected separately.

It is certain that these recycling capacities have developed more in comparison with the reduced quantities of separately collected and / or recycled waste. Thus, the current recycling capacity is much higher than the quantities collected separately of recyclable municipal waste.

\section{DIFFICULTIES AND RESTRICTIONS IN THE RECYCLING OF MUNICIPAL WASTE}

In Romania, there is a low collection of recyclable waste, followed by a growing recycling capacity. Thus, in 2016 , only $13.3 \%$ of the amount of waste was recycled (Romania is placed in the last places in the EU). This aspect shows the poor management of municipal waste and, in particular, of bulky waste (untreated waste accepted for storage).

The deficiencies are in particular in the nature of regulations, the lack of technical norms on composting, mechanical-biological treatment and thermal treatment facilities. In addition to this important aspect, there is no correlation between the CAEN codes for waste management activities, namely their activities and codes, as described and classified by specific legislation. Order of the Ministry of Environment no. 1798/2007 for the approval of the environmental permit issuance procedure (completed and subsequently amended) does not contain special provisions regarding the authorization of the waste management activities and the obligation to specify in the environmental permit the recovery / disposal activity code and the managed waste codes. Non-correlation has been observed, between the provisions of Law no. 101/2006 of the sanitation service of the localities republished and the provisions of the subsequent orders of the president of ANRSC.

The national list of waste accepted in non-hazardous waste landfills does not prohibit the storage of separately collected waste, but it is only recommended to apply one recovery method.

Other aspects of institutional / organizational nature can be mentioned:

1. the insufficient involvement of the local public administration authorities in fulfilling their obligations regarding the collection and management of municipal waste;

2. there is no nationally agreed model for a framework delegation contract for the municipal waste management sanitation service that regulates the relationship between the territorial / ADI units and the sanitation service 


\section{\#3/2018 URBAN CHALLENGES}

operators and includes indicators for monitoring the performance of the provided activity;

3. major delays during the procedures for awarding delegation contracts to the sanitation service management;

4. the low institutional capacity of both environmental authorities and local authorities and ADI (Intercommunity Development Associations) in the field of waste;

5. the existence of a heterogeneous system with regard to the payment mechanism of the sanitation service, which also leads to difficulties in the correct implementation of economic instruments; In accordance with the provisions of OUG no. 196/2005, the amounts collected as a result of applying the economic instruments in the field of waste are not used exclusively for waste projects;

6. the lack of obligation of economic operators to report to the Integrated Environmental System managed by the National Agency for Environmental Protection;

7. there is no national data and information resulting from the analysis of municipal waste characteristics and domestic waste generation indicators by average for the purpose of establishing benchmarks and comparisons for reported data.

\section{CONCLUSIONS}

In conclusion, recycling is an important part of a modern urban lifestyle that should be cataloged and sustainable.

Although there is much information about recycling, this process is often ignored. Often, neither the actual size of recycling on the quality of urban life is known, nor is the impact of non-recycling.

In Europe, much of the existing waste has begun to be recycled, some countries reaching a rate of over $50 \%$ (Germany $66.1 \%$, Austria $57.6 \%$, Belgium $53.5 \%$ and the Netherlands $53.1 \%$ ). These countries are aware that recycling clearly brings environmental benefits by eliminating waste from landfills and supplying raw materials for new products.

Recently, the EU has launched a new development perspective based on the Circular Economy, which also includes many regulations on waste.

In Romania, the situation of urban waste recycling is far from being solved, supported by the small recycling rate in 2016 , of only $13.3 \%$. Although there are significant recycling capacities, waste is not collected or is collected without being separated. Many of them are thrown into the water or left to chance on the ground, causing significant damage to the environment and human health in urban areas.

Throughout this story of municipal waste recycling, an important place should be given to waste management and planning their management. Urban areas should design management plans that would allow, as a first step, to assess the existing 
situation but also to define the objectives, formulate the strategy and identify the resources and means of implementation.

Currently viewed as an opportunity and also a challenge, the recycling of waste due to the rapid, economic and social growth of cities has a positive impact on the local environment (air, water, land, human health etc.). Therefore, the complexity, costs and coordination of waste management require the involvement of all stakeholders, but also financial resources, including the identification of new technologies, research actions and eco-innovation. 


\section{REFERENCES}

[1] Antonescu D., "Liveable city from the economic perspective", http://www.julpreview.ro/files/Antonescu-D.pdf, 2017

[2] ILCD Handbook: General guide for Life Cycle Assessment - Detailed guidance, European Commission, 2010.

[3] Awan, A. "Shifting Global Economic Paradigm". Asian Business Review, 4(3), 35-40, http://ischolar.in/index.php/ABRABC/article/view/58256, 2014.

[4] Brunner, P.-H. \& Rechberger, H., "Practical Handbook of Material Flow Analysis. Advanced Methods in Resource and Waste Management". Lewis Publishers, CRC Press LLC, 2004.

[5] Deo, B. S., "Materials Flow Analysis (MFA) - a Translation Problem for Management". IIE Annual Conference, 2005.

[6] Dewan, H., "Sustainability Index: An Economics Perspective". http://economics.ca/2006/papers/0409.pdf, 2006.

[7] Miafodzyeva S., "Understanding the Recycling Behaviour of Householders in Multicultural Urban Areas: Case Study Järva", Stockholm, https://pdfs.semanticscholar.org/45a2/76937e011c0c5544672de14228c326a3cd87. pdf

[8] Karen Polenske, Li Xin, Chen Zhiyu, James Hamilton, "Recycling Industrial Land for Urban Redevelopment", Department of Urban Studies and Planning, Massachusetts Institute of Technology, publish in Workshop on Global Innovations, World Bank, 2009.

[9] Dodgson, J.S., Spackman, M., Pearman, A., Phillips, L.D., "Multi-criteria analysis: A manual". Department for Communities and Local Government: London. ISBN 9781409810230, 2009.

[10] https://www.gdrc.org/sustdev/concepts/04-e-effi.html

[11] https://www.sciencedirect.com/science/article/pii/S1877705815021918

[12] How to Calculate the MSW (Municipal 4 Solid Waste) Recycling Rate, http://www.wasteauthority.wa.gov.au/media/files/documents/GN4MSWRates.pdf

[13] Ivan Nikolić, "Urban recycling of derelict industrial sites. Analysis of socioeconomic redevelopment of post-industrial districts", https://upcommons.upc.edu/bitstream/handle/2099.1/21140/IvanNikolic.pdf, 2013.

[14] Directive no. 94/62 / EC, Directive no. 99/31 / EC on the storage of waste, Council Directive no. 2000/76 / EC on the incineration of waste, Council Directive no. 2002/96 / EC on Electrical and Electronic Equipment Waste (WEEE), Regulation No. $259 / 93$ on the import, export and transit of waste.

[15] Eurostat, www.eurostat.com

[16] Albino V., Fraccascia L., Savino T., "Industrial Symbiosis for a Sustainable City: Technical, Economical and Organizational Issues", https://www.sciencedirect.com/science/article/pii/S1877705815021918 , 2016.

[17] https://www.tommc.de/fileadmin/pdf/2017/170828 Obermeier Calculation methods for recycling ra tes.pdf

[18] http://ec.europa.eu/environment/waste/target review.htm [19] NATIONAL WASTE MANAGEMENT PLAN 2014-2020, http://www.mmediu.ro/app/webroot/uploads/files/PNGD vers5.pdf

[20] The National Agency for Environmental Protection Data. 
Article distributed under a Creative Commons AttributionNonCommercial-NoDerivatives 4.0 International License (CC BY-NC-ND).

Received: April 19, 2018

Accepted: May 4, 2018. 